\title{
Effect of Irrigation Method and Non-Uniformity of Irrigation on Potato Performance and Quality
}

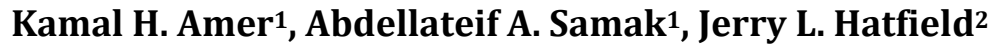 \\ ${ }^{1}$ Department of Agricultural Engineering, Menofia University, Menofia, Egypt \\ ${ }^{2}$ USDA-ARS National Laboratory for Agriculture and the Environment, Ames, IA, USA \\ Email: kamalamer@yahoo.com
}

Received 7 February 2016; accepted 14 March 2016; published 17 March 2016

Copyright () 2016 by authors and Scientific Research Publishing Inc.

This work is licensed under the Creative Commons Attribution International License (CC BY).

http://creativecommons.org/licenses/by/4.0/

(c) (i) Open Access

\begin{abstract}
Potato growth, yield, and quality under improved irrigation methods and non-uniformity of their irrigation applications are important to enhance water management in arid regions. A field experiment was conducted in $\mathbf{2 0 1 4}$ spring and fall growing seasons using potato (Solanum tuberosum) grown in northern Egypt at Shibin El Kom, Menofia, Egypt to evaluate potato response to furrow or trickle irrigation. A Randomized Split-Plot Design with irrigation method randomly distributed and non-uniformity of irrigation applications evaluated along either irrigation furrow or trickle lateral as dependent variables measured at the $3^{\text {rd }}, 13^{\text {th }}, 23^{\text {rd }}, 33^{\text {rd }}, 43^{\text {rd }}$ and $53^{\text {rd }} \mathrm{m}$ along the $55 \mathrm{~m}$ irrigation line. Traditional (TF) and partial (PF) furrows as well as trickle point (TP) and line (TL) sources were used as irrigation methods. Each treatment was repeated three times. For a $33^{\text {rd }} \mathbf{~ m}$ treatment, seasonal optimum water use by potato was 328, 234, 269 and $292 \mathrm{~mm}$ over 118 days in spring and 200, 164, 178 and $186 \mathrm{~mm}$ over 122 days in fall under TF, PF, TP and TL irrigation methods, respectively. Potato tuber yield and quality were significantly affected by growing season (S), irrigation method (I) and non-uniformity of irrigation application (U). Tuber yield, total soluble solid (TSS) and leaf area index (LAI) were significantly affected by I and U, and their interaction I * $U$; harvest index (HI) was not affected by I but U. Except for TSS by $S$ * I and HI by $U$ * I and $S$ * I, results showed no significant differences. Moreover, tuber weight, number and marketable yield were significantly affected by $S, I, U$ and $I * U$ interaction, except medium tuber size and culls by $S$. A given $33^{\text {rd }}$ treatment under partial furrow and trickle irrigation, relative to that of traditional furrow, enhanced tuber yield and improved quality in both growing seasons. In non-uniform irrigation application over two growing seasons, potato crop response was developed under varied irrigation methods. Tuber yields were significantly affected in a linear relationship $\left(r^{2} \geq\right.$ 0.75 ) by either water deficit or excessive water under irrigation methods.
\end{abstract}

\section{Keywords}

Potato Yield and Quality, Furrow Irrigation, Trickle Irrigation, Scheduling, Crop Coefficient 


\section{Introduction}

Limited fresh water resources are a serious issue worldwide particularly in arid and semi-arid regions. Furthermore, available supplies of fresh water are decreasing due to increased population growth, low precipitation, competing demands from industry, agricultural and urban development. Alternative sources of water such as seawater, storm water, wastewater, and industrial wastewater are expensive and produce a lesser amount of water. Therefore, more efficient water management with proper irrigation method is critical for optimization of crop production and maximization of return yield. Trickle and sprinkler irrigation systems, respectively, achieve water saving up to $50 \%$ and $30 \%$ compared with surface irrigation [1] [2]. In some cases, trickle or surface irrigation is better than sprinkler irrigation as any moisture on the leaves increases the potential for leaf disease. In smallholdings using irrigation gated pipes and double planting row bed, partially wetted furrow irrigation achieves water saving as trickle irrigation; furthermore, it decreases installation cost compared with other systems [3] [4].

Soil water flow under trickle irrigation is described as line source, two-dimensional or point source, threedimensional depending on the distance between emitters along a lateral according to [5] [6]. In case of a line source, emitters are spaced in order to produce a continuous strip of wetted soil along the row. The distances between emitters would determine the degree of overlap between neighboring wetted circles. Therefore, wetted soil area as related to the discharge per unit length is best to consider under line source. In case of trickle point source, wetted soil volume is heterogeneous in water distribution and surrounded by drier soil. It is described by wetting depth and diameter measured at its widest points. Water infiltration in furrow irrigation can be one-, two- and three-dimensional process [7]. In one-dimensional infiltration which occurred in conventional furrow irrigation, a horizontal plane is considered and the infiltration streamline is vertical. In two-dimensional infiltration which represented partial furrow in this work, ponding of water in a semicircular furrow cross section is considered and water flows in the horizontal and vertical directions. Three-dimensional infiltration only occurred in the case of a semispherical surface and water flows in three dimensions.

Potato (Solanum tuberosum) is predominantly grown on large fields in arid or semiarid where tuber yield and quality are promoted by irrigation [8] [9]. More arid climates can have comparative advantages in potato productivity due to more sunlight and lower relative humidity. Lower relative humidity favors plant health. Yet, at every phase of development from early vegetative growth, through tuber set, and tuber bulking, potato is sensitive to soil moisture deficits and excesses. Potato plants grow best on fertile, well drained soil with added organic matter of $17 \mathrm{Mg} / \mathrm{ha}$ farmyard manure before planting. Potato roots, most of which are in the top of $40-50$ cm of soil, develop rapidly [10] [11]. Irrigation should be scheduled to avoid excessive moisture or water stress. Lack of adequate soil water at tubers development can result in misshapen tubers, but too much soil water can aggravate root and tuber rot diseases. Reference [12] examined the effects of different irrigation treatments on the tuber development of potato crops in Northern China. They found that high frequency irrigation enhanced potato tuber growth and water use efficiency. Reducing irrigation frequency from once every day to once every 8 days resulted in significant yield reductions by $33.4 \%$ and $29.1 \%$ in 2001 and 2002, respectively.

Potato is an important commercial crop that has gained popularity in the Mediterranean region [12]-[14]. Potato is normally grown in soil under conditions using trickle, sprinkler and furrow irrigation methods during spring and fall seasons in order to respond to the high demand of potato on both national and international markets. Reference [12], working on potato, stated that potato tuber yield, single tuber weight, and tuber number of 10 plants, tuber grading, and water use efficiency were significantly higher in 2011 growing season than those obtained on 2002 growing season. Moreover, higher results were obtained when they irrigated potato field once every day in which well-watered conditions occurred.

Irrigation management requires the simultaneous achievement of effective water use for profitable production and environmental protection. Considering all other factors of production at their optimum level, crop response is defined as a crop reduction occurred by either deficit or excessive water applied into the root zone more than optimum water use by plants [10] [15] [16]. Reference [10] stated that irrigation in excess of crop use should be minimized due to the risk of leaching of nitrate and pesticide residues towards groundwater and the risk of runoff losses of sediment and nutrients to surface water. Excessive irrigation promotes potato diseases because potato crop has shallow roots and sensitive to water stress. Water deficits reduce tuber yields and quality. Tuber grade is highly sensitive to irrigation management deficiencies. Together these tuber responses to deficit irrigation make potato a challenging crop to irrigate. Research has developed techniques to determine ideal irrigation 
timing based on allowable soil water depletion ASWD, soil water tension SWT, and crop evapotranspiration $\mathrm{ET}_{\mathrm{c}}$. Irrigation amounts are based on soil water status or $\mathrm{ET}_{\mathrm{c}}$. Sprinkler irrigation systems are generally superior to furrow systems for potato production. Trickle irrigation systems are used in specialized production circumstances and are the subject of intensive research. But, trickle irrigation has been frequently used in most crop commodities, mainly for vegetables and fruits, to improve water use efficiency and nutrition supply because of cost of installation has relatively decreased with improving technology [8]. Finally, they concluded that optimal irrigation management for potato crop is demanding because both under and over irrigations have clear negative consequences.

Comparing furrow with trickle irrigation systems, Reference [8] working on potato grown under furrow and trickle irrigation methods and subjected to three deficit irrigation levels, found that the adequate water amount for furrow and trickle was $554 \mathrm{~mm}$ and $417 \mathrm{~mm}$ in well water condition, respectively. Rainfall during the total growing period was $50 \mathrm{~mm}$. For each irrigation method, treatment differences for tuber yield were statistically significant at the 0.05 confidence level according to analysis of variance. As would be expected, the highest tuber yields were obtained from non-stressed treatments and the lowest tuber yield was obtained from the deficit irrigation treatments. These results were in agreement with those obtained by [17] working on potato.

The purpose of the study was to assess the yield and quality of potato under irrigation systems of traditional and partial furrows and trickle point and line sources and evaluate the uniformity of water applied for a given irrigation system on potato production in spring and fall growing seasons. A goal of the study was to determine the optimal irrigation amounts for a potato crop given the non-uniformity of irrigation systems.

\section{Materials and Methods}

Potato cultivar Diamant (Solanum tuberosum) was grown in 2014 spring and fall growing seasons in clay loam soil located at an arid site in northern Egypt (Shibin El-Kom area, $17.9 \mathrm{~m}$ above sea level, 30 32/N, 31 $03 / \mathrm{E}$ ). The field was leveled to $0.1 \%$ slope. All treatments were irrigated each growing season with the same sufficient water amount using surface irrigation to ensure uniform soil moisture prior to planting. The crop was seeded when soil moisture content was almost $0.39 \mathrm{~m}^{3} \cdot \mathrm{m}^{-3}$ using potato planter on 3 October and 23 February, and terminated on 2 January and 18 May in the 2014 spring and fall growing seasons, respectively. A randomized split plot design with four irrigation methods randomly distributed and six irrigation applications systematically measured along irrigation line (Figure 1). Plot size for a replicate which included all treatments was $55 \times 17.85$ $\mathrm{m}$ with $0.7 \mathrm{~m}$ row width, and $0.3 \mathrm{~m}$ spacing between plants within rows. Plant population was 47,619 plants ha ${ }^{-1}$. Irrigation method treatments were separated by $1.5 \mathrm{~m}$ non-irrigated area to avoid horizontal soil water movement. Four irrigation methods were used and designed as traditional furrow TF, one-dimensional, partial furrow $\mathrm{PF}$, two-dimensional, trickle point source TP, three-dimensional, and trickle line source TL, two-dimensional soil water flow. TF was $0.7 \mathrm{~m}$ width with a single planting row bed. PF was $1.4 \mathrm{~m}$ width with double planting row bed. TP was a trickle lateral with $0.6 \mathrm{~m}$ emitter spacing for a plant row and an emitter for two plants in the same row. TL was a trickle line with $0.3 \mathrm{~m}$ emitter spacing for two plants in the two adjacent rows. Non-uniformity of six irrigation depths U3, U13, U23, U33, U43 and U53 were methodically measured at the $3^{\text {trd }}, 13^{\text {th }}$, $23^{\text {rd }}, 33^{\text {rd }}, 43^{\text {rd }}$, and $53^{\text {rd }} \mathrm{m}$ along $55 \mathrm{~m}$ furrow or trickle lateral, respectively. Each treatment was repeated three times with 4 rows for each irrigation method with a $2.8 \mathrm{~m}$ width and $55 \mathrm{~m}$ length. Watermark 253 soil moisture sensors ${ }^{1}$ (Campbell Scientific Inc., Logan, Utah) with a digital reader were set in each $33^{\text {rd }} \mathrm{m}$ each treatment and calibrated by taking gravimetric soil samples. At the beginning of each experiment, a relationship between sensor readings and sampled soil moisture content was established. Sensors were vertically installed for all irrigation methods at 0 - 10, 10 - 20, 20 - 30, 30 - 40, 40 - 50, 50 - 60 and 60 - $70 \mathrm{~cm}$ depths and horizontally installed except TF method at 0 - 10, $10-20,20-30,30-40,40-50,50-60$, and $50-70 \mathrm{~cm}$ for each $10 \mathrm{~cm}$ vertical soil depth interval. Treatments were regularly irrigated when volumetric soil moisture content reached in between 0.32 and $0.35 \mathrm{~m}^{3} \cdot \mathrm{m}^{-3}$ in the upper $0.7 \mathrm{~m}$ of soil profile at $33^{\text {rd }} \mathrm{m}$ stations. Sensors readings were periodically monitored each irrigation interval. For a U33 treatment, soil-water redistribution after $36 \mathrm{~h}$ from irrigation under both furrow and trickle irrigations were plotted using sensor readings.

Furrow and trickle irrigation systems were installed just after potato seeding in the experiment. The control unit of both irrigation systems consisted of a pressurized water supply, flow meter, pressure gage, and control valves (Figure 1). For two furrow methods, inlet water flow rate was $2.4 \mathrm{~m}^{3} \cdot \mathrm{h}^{-1}$ in each furrow using gated pipe.

\footnotetext{
${ }^{1}$ Mention of a specific product or trade name does not imply endorsement.
} 


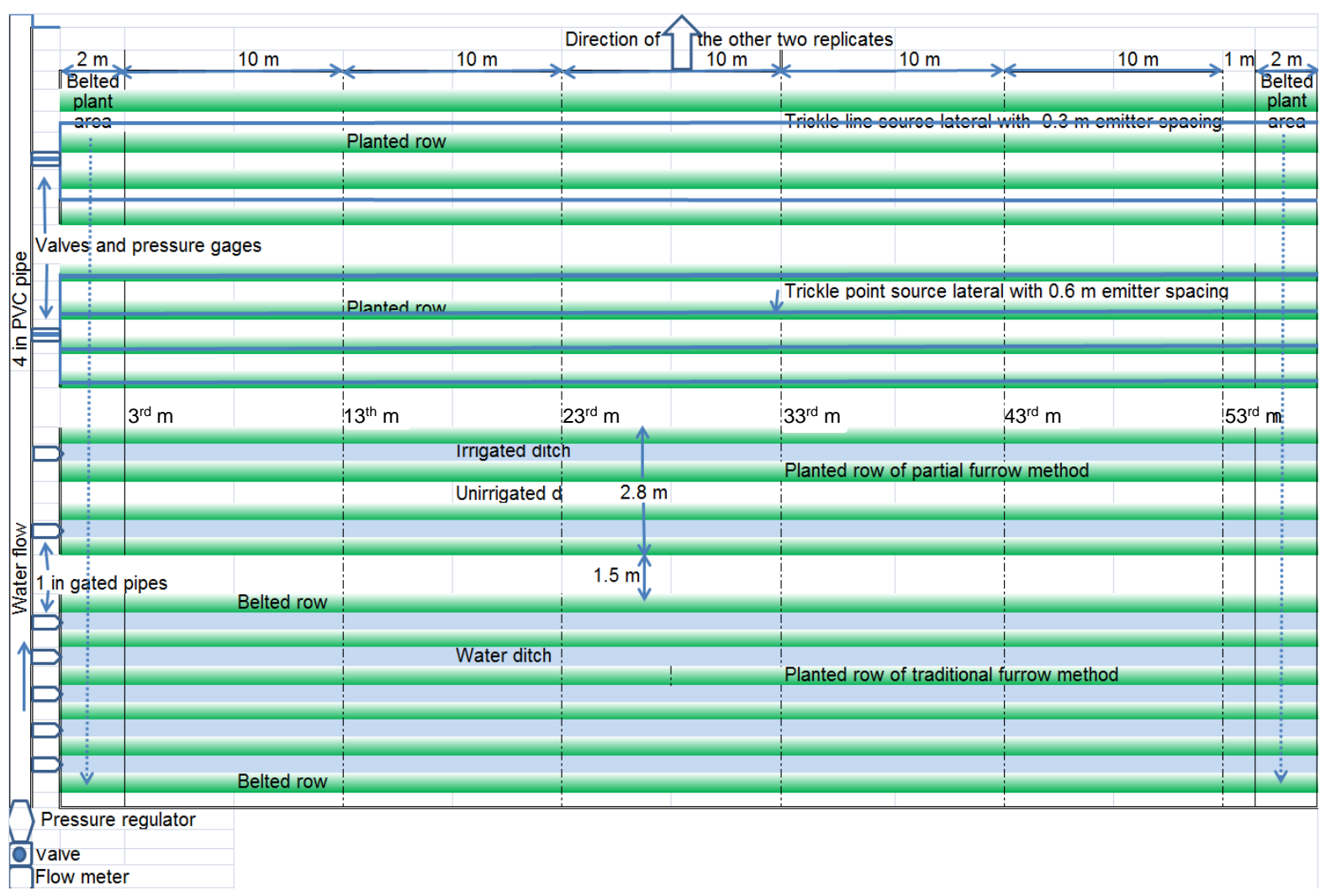

Figure 1. Potato experiment layout with irrigation method treatments which randomly distributed in each replicate.

Water flow was left to advance downstream the $55 \mathrm{~m}$ blocked-end furrow length and remain for 5 min storage time. Advance and recession times were measured each $5 \mathrm{~m}$ along the $55 \mathrm{~m}$ blocked-end furrow. For two trickle methods, emitters with $8 \mathrm{l} / \mathrm{h}$ flow rate and $3 \mathrm{~mm}$ barb diameter operating at $101 \mathrm{kPa}$ pressure were spaced 0.6 and $0.3 \mathrm{~m}$ as trickle point and line sources, respectively, using 18 and $15.6 \mathrm{~mm}$ outer and inner diameter-Polyethylene tube. Inlet pressure was adjusted as 115 and $125 \mathrm{kPa}$ with 1.0 and $1.25 \mathrm{~h}$ flowing time per irrigation for trickle point and line sources, respectively.

Farmyard manure of $17 \mathrm{Mg} \cdot \mathrm{ha}^{-1}$ was added and distributed into soil surface at the beginning of each potato season. Fertilizer (150 kg.ha ${ }^{-1} \mathrm{~N}, 60 \mathrm{~kg} \cdot \mathrm{ha}^{-1} \mathrm{P}$, and $\left.70 \mathrm{~kg} \cdot \mathrm{ha}^{-1} \cdot \mathrm{K}\right)$ was applied uniformly at the early to full growing vegetative stages across the experiment as recommended for potato production in this area.

Soil was classified as clay loam with $1.28 \mathrm{~g} \cdot \mathrm{cm}^{-3}$ bulk density, non-saline and alkaline $\left(\mathrm{EC}_{\mathrm{e}}=1.4 \mathrm{dS} / \mathrm{m}\right.$, SAR $=5.8$ and $\mathrm{pH}=8.1$ ). Irrigation water applied used pressurized fresh water with an $\mathrm{EC}=0.89, \mathrm{SAR}=2.8$ and $\mathrm{pH}$ $=8.3$. Soil particle sizes of the average of the upper $0.7 \mathrm{~m}$ soil profile were distributed as $18.3 \%$ sand, $38.4 \%$ silt, and $43.3 \%$ clay. Volumetric water content values measured using pressure membrane were $65.2,43$, and 22.4\% at saturated, field capacity and wilting points, respectively. Soil water infiltration was measured in the upper 30 $\mathrm{cm}$ of soil surface using a double ring infiltrometer. An empirical equation was found in experimental site for clay loam soil to express the infiltration rate $\mathrm{I}$ in $\mathrm{mm} \cdot \mathrm{min}^{-1}$ as a function of opportunity time $\left(\mathrm{t}_{0}\right)$ in minute as $\mathrm{I}=$ $3.382 \mathrm{t}_{\mathrm{o}}^{-0.458}$. Cumulative infiltrated depth $\mathrm{Z}$ in mm was integrated as $\mathrm{Z}=6.24 \mathrm{t}_{0}^{0.542}$. An average value of minimum infiltration rate which considered as saturated hydraulic conductivity $\mathrm{k}_{\mathrm{s}}$ was recorded as $32 \mathrm{~mm} \cdot \mathrm{h}^{-1}$ for pretreatments. Catch cans were used to collect water each $5 \mathrm{~m}$ for the three emitters started at the $3^{\text {rd }}$ and ended at $53^{\text {rd }} \mathrm{m}$ along $55 \mathrm{~m}$ irrigation lateral. In addition to measuring collected water, soil samples were taken at the foregoing stations for trickle and furrow lines in order to determine water application and infiltrated in rootzone along the $55 \mathrm{~m}$ potato rows.

Irrigation amounts were determined and adjusted according to soil moisture readings under furrow and trickle irrigation methods using the following equation:

$$
d=\left(\theta_{f c}-\theta_{p w p}\right) D \cdot \mathrm{MAD} \cdot P
$$


where $d$ is scheduling irrigation depth (mm), $\theta_{f c}$ and $\theta_{p w p}$ are, respectively, soil moisture content at field capacity and permanent welting point $\left(\mathrm{m}^{3} \cdot \mathrm{m}^{-3}\right), D$ is wetted soil root depth $(\mathrm{mm})$, MAD is management available deficit (fraction), and $P$ is wetted volume fraction. $P$ was derived in this study using both soil moisture contour lines after irrigation water redistribution and flow rates of emitter, line source, or furrow as follows:

$$
P=\frac{\sum_{j=1}^{n} V_{j}\left(\theta_{j}-\theta_{i}\right)}{V\left(\theta_{f c}-\theta_{i}\right)}
$$

where $\theta_{j}$ final soil moisture content between two contour lines after soil-water redistribution $\left(\mathrm{m}^{3} \cdot \mathrm{m}^{-3}\right)$ for soil wetted volume $V_{j}, \theta_{i}$ is initial soil moisture content $\left(\mathrm{m}^{3} \cdot \mathrm{m}^{-3}\right), V$ is used soil volume per potato plant. The part $\sum_{j=1}^{n} V_{j}\left(\theta_{j}-\theta_{i}\right)$ represents the amount of irrigation per used area. Equation (1) was also used to determine water used by potato as multiplying soil root depth times water deficit between two irrigation dates.

The study area was in a warm Mediterranean climate as shown in Table 1 characterized by moderate seasonal variation, with the lowest average temperature in January (monthly average $13.04^{\circ} \mathrm{C}$ ) and the hottest period between June and August (monthly average $27.4^{\circ} \mathrm{C}$ to $28.5^{\circ} \mathrm{C}$ ). In the experimental site, 8.2 and $4.3 \mathrm{~mm}$ rainfall occurred on 13 and 31 December 2014, respectively and there was no ground water contribution because the water table was greater than $2.8 \mathrm{~m}$ during the study period. Class $\mathrm{A}$ pan evaporation $\mathrm{E}_{\mathrm{p}}$ data were monthly recorded as in Table 1. Reference evapotranspiration $\mathrm{ET}_{\mathrm{o}}$ was determined from weather data collected at Shibin El Kom area using FAO56 Penman-Monteith [18]. Weather variables (temperatures, relative humidity, wind speed, and radiation) were measured in experimental area by an automatic weather station as described by [19]. Potato crop coefficient was found as dividing water use by FAO56 $\mathrm{ET}_{0}$ during irrigation interval in 2014 spring and fall growing seasons.

Potato crop response was relatively found as a relation between potato yield and its corresponding water use depth. Tuber yield as well as its cumulative water depth was seasonally measured at the $3^{\text {rd }}, 13^{\text {th }}, 23^{\text {rd }}, 33^{\text {rd }}, 43^{\text {rd }}$ and $53^{\text {rd }} \mathrm{m}$ along $55 \mathrm{~m}$ furrow or trickle lateral. For a given irrigation method, relative potato yield $\mathrm{Y} / \mathrm{Y}_{\mathrm{m}}$ was determined by dividing potato yield $\mathrm{Y}$ by its maximum yield $\mathrm{Y}_{\mathrm{m}}$. Relative water depth $\mathrm{W} / \mathrm{W}_{\mathrm{m}}$ were obtained by dividing water depth $\mathrm{W}$ by its optimum depth $\mathrm{W}_{\mathrm{m}}$.

Table 1. Monthly weather data at Shibin El-Kom, Egypt during 2014 spring and fall growing seasons.

\begin{tabular}{|c|c|c|c|c|c|c|c|c|c|}
\hline \multirow{2}{*}{ Month } & $\mathrm{T}_{\mathrm{avg}}{ }^{*}$ & $\mathrm{~T}_{\max }$ & $\mathrm{T}_{\min }$ & $\mathrm{RH}_{\mathrm{avg}}$ & $\mathrm{U}_{2}$ & $\mathrm{R}_{\mathrm{s}}$ & $\mathrm{R}_{\mathrm{n}}$ & $\mathrm{ET}_{\mathrm{o}}$ & $\mathrm{E}_{\mathrm{p}}$ \\
\hline & ${ }^{\circ} \mathrm{C}$ & ${ }^{\circ} \mathrm{C}$ & ${ }^{\circ} \mathrm{C}$ & $\%$ & $\mathrm{~m} \cdot \mathrm{s}^{-1}$ & $\mathrm{MJ} \cdot \mathrm{m}^{-2} \cdot \mathrm{d}^{-1}$ & $\mathrm{MJ} \cdot \mathrm{m}^{-2} \cdot \mathrm{d}^{-1}$ & $\mathrm{~mm} \cdot \mathrm{d}^{-1}$ & $\mathrm{~mm} \cdot \mathrm{d}^{-1}$ \\
\hline Feb. & 14.10 & 20.73 & 8.42 & 63.22 & 0.54 & 12.63 & 6.23 & 1.76 & 2.41 \\
\hline March & 15.2 & 21.67 & 12.48 & 63.02 & 0.62 & 16.70 & 8.82 & 2.41 & 3.91 \\
\hline April & 21.41 & 30.2 & 14.21 & 55.40 & 0.85 & 18.42 & 10.10 & 3.54 & 4.92 \\
\hline May & 23.86 & 32.65 & 16.67 & 51.90 & 0.89 & 21.10 & 12.24 & 4.15 & 6.02 \\
\hline June & 27.40 & 35.85 & 19.74 & 52.57 & 0.68 & 21.67 & 12.82 & 4.37 & 7.52 \\
\hline July & 28.43 & 36.42 & 20.74 & 61.36 & 0.58 & 21.74 & 13.51 & 4.57 & 7.06 \\
\hline Aug. & 28.47 & 35.94 & 22.05 & 62.12 & 0.57 & 21.05 & 12.71 & 4.30 & 7.11 \\
\hline Sept. & 27.32 & 36.41 & 20.15 & 59.96 & 0.55 & 20.89 & 11.86 & 4.02 & 6.80 \\
\hline Oct. & 23.95 & 31.94 & 16.95 & 61.72 & 0.64 & 15.78 & 8.81 & 2.90 & 4.43 \\
\hline Nov. & 20.91 & 28.12 & 14.87 & 64.31 & 0.49 & 12.03 & 5.94 & 1.98 & 3.12 \\
\hline Dec. & 15.88 & 23.76 & 10.21 & 69.28 & 0.69 & 9.50 & 4.62 & 1.56 & 2.03 \\
\hline Jun. 2015 & 13.04 & 19.14 & 8.30 & 69.97 & 0.94 & 8.17 & 4.03 & 1.34 & 1.61 \\
\hline
\end{tabular}

$* \mathrm{~T}_{\text {avg }}, \mathrm{T}_{\max }$, and $\mathrm{T}_{\min }$ are average, maximum, and minimum temperatures, respectively, $\mathrm{RH}_{\mathrm{avg}}$ is average relative humidity, $\mathrm{U}_{2}$ is average wind speed, $R_{s}$ is average solar radiation, $R_{n}$ is average net radiation, $E_{0}$ is average reference evapotranspiration (Allen et al., 1998), and $E_{p}$ is average of measured pan evaporation class A. 
Leaf area per plant each replicate was measured for full vegetative growth on 2014 spring and fall growing seasons in field situation by drawing leaves on a scale paper and using planometer to measure leaf area. Leaf area index LAI was determined by dividing plant leaf area per unit ground area. At the end of each growing season, six plants were collected from each replicate to determine total biomass. Potato tubers were separated from vegetative material to determine potato tuber yield and both plant components individually dried at $70^{\circ} \mathrm{C}$ until achieving constant weight to determine the dry weight. Dry matter of plant and its components were considered as plant total soluble solid TSS. Harvest index HI was determined as a ratio of potato tuber to total biomass production on a dry mass basis. Potato tuber weight, number, and grading percentages were evaluated for each replicate. Standard grading for potato tubers was, respectively, found $\geq 150 \mathrm{~g}, 150 \mathrm{~g} \geq \mathrm{W} \leq 100 \mathrm{~g}, 100 \mathrm{~g} \geq$ $\mathrm{W} \leq 50 \mathrm{~g}$, and $\geq 50 \mathrm{~g}$ for large, medium, small, and culls according to [20].

The statistical analysis of the experimental data was carried out using the Statistical Analysis System [21]. Analysis of variance was performed to measured data. Duncan, at $5 \%$ significant level, was used to determine the statistical differences among means. Significance evaluation was hypothesized based on $5 \%$ significant level $(\mathrm{p} \leq 0.05)$.

\section{Results and Discussion}

\subsection{Wetted Soil Volume and Fraction across Irrigation Line}

In traditional furrow irrigation (1-D soil water flow), cross-sectional area of potato root depth was symmetrically watered, therefore, wetted volume fraction, $P$ in Equation (2), was considered as unity. Wetted soil patterns after soil-water redistribution were experimentally found for partial furrow (2-D soil water flow) and trickle point (3-D soil water flow) and line sources (2-D soil water flow) irrigation methods at the $33^{\text {rd }} \mathrm{m}$ along irrigation line, respectively, in Figures 2-4. In partial furrow irrigation (Figure 2) with applying $2.4 \mathrm{~m}^{3} \cdot \mathrm{h}^{-1}$ inlet flow rate in clay loam soil which was initialized at $0.325 \mathrm{~m}^{3} \cdot \mathrm{m}^{-3}$ moisture content, infiltrated irrigation depth in furrow cross-section area was maximized at $20 \mathrm{~cm}$ distance from water source. Infiltrated depth for $1.4 \mathrm{~m}$ width and 0.7 $\mathrm{m}$ depth was average as $27.3 \mathrm{~mm}$. In the half of the furrow cross-section with $0.031 \mathrm{~m}^{2}$ ditch area, soil moisture content was, relatively, decreased as soil depth from water source increased. Fraction of wetted soil area P to total area in partial furrow treatment was 0.507 as calculated from Equation (2). In trickle point source (Figure 3) with applying $8 \mathrm{l} / \mathrm{h}$ emitter flow rate for $1 \mathrm{~h}$ operating duration with $0.34 \mathrm{~m}^{3} \cdot \mathrm{m}^{-3}$ initial soil moisture content, soil moisture content after soil-water redistribution in $0.252 \mathrm{~m}^{3}$ hemispherical wetted soil volume was distributed as $0.42 \mathrm{~m}^{3} \cdot \mathrm{m}^{-3}$ around point source and decreased to $0.34 \mathrm{~m}^{3} \cdot \mathrm{m}^{-3}$ at distance $0.5 \mathrm{~m}$ from the point source. Thus, wetted soil volume fraction $P$ using Equation 2 was determined as 0.35 in trickle point source method. Maximum infiltrated irrigation depth under trickle point source in Figure 3 was occurred at zero point of soil wetted volume and decreased with distance from the axis of soil wetted volume. In trickle line source (Figure 4) with applying $26.6 \mathrm{l} / \mathrm{m} / \mathrm{h}$ line flow rate for $1.25 \mathrm{~h}$ operating duration with $0.33 \mathrm{~m}^{3} \cdot \mathrm{m}^{-3}$ initial soil moisture content, soil water redistribution were decreased as distance increased from the trickle line source in 2-dimensional direction. Wetted soil area fraction $P$ related to emitter served area in trickle line source treatment was 0.381 . Infiltrated irrigation depth in Figure 4 occurred at zero point and decreased as distance from trickle line increased. Average of soil irrigation depth was $21.2 \mathrm{~mm}$ under trickle line source. It seemed that wetted soil volume was symmetrically infiltrated along furrow and trickle line source, but, it was smoothly surrounded in hemispherical shape under trickle point source. Thus, wetted soil fraction was determined based on two-dimensional flow along furrow and trickle line source, but it was using hemispherical wetted volume under trickle point source. These results are in agreement with those of [4] comparing trickle source with furrow method.

\subsection{Infiltrated Irrigation Depth and Uniformity along Irrigation Line}

Infiltrated irrigation depth was found along irrigation line as illustrated in Figure 5. Schedule irrigation depth $\mathrm{W}_{\mathrm{m}}$ occurred at $33^{\text {rd }} \mathrm{m}$ was maximized $47.7 \mathrm{~mm}$ under TF and minimized $19.6 \mathrm{~mm}$ under TP method. Coefficient of variation CV of infiltrated irrigation depths along $55 \mathrm{~m}$ of TF, PF, TP, and TL methods was achieved $14.3 \%, 20.0 \%, 13.5 \%$, and $23.6 \%$, respectively. Irrigation uniformity as a function of CV was highly achieved for TP followed by TF compared with PF and TL methods because the first two methods were designed an irrigation line for a planting row (inlet water flow for $0.7 \mathrm{~m}$ width) and the latter two methods were an irrigation line for two planting rows (inlet water flow for $1.4 \mathrm{~m}$ width). Each irrigation method was scheduled based on measured soil moisture content at the $33^{\text {rd }} \mathrm{m}$ in which schedule irrigation depth (d) and average water applied 


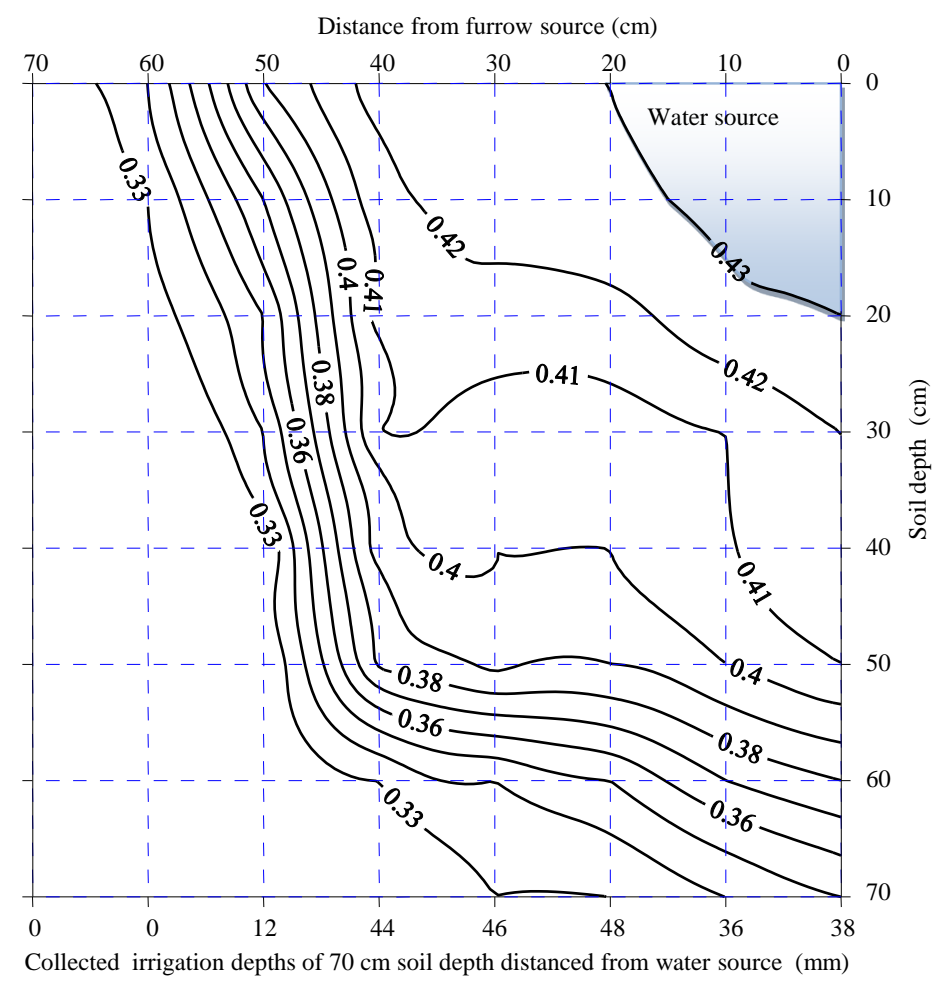

Figure 2. Volumetric moisture content after soil-water redistribution under partially wetted furrow irrigation with $2.4 \mathrm{~m}^{3} \cdot \mathrm{h}^{-1}$ inlet flow rate and $50 \mathrm{~m}$ length.

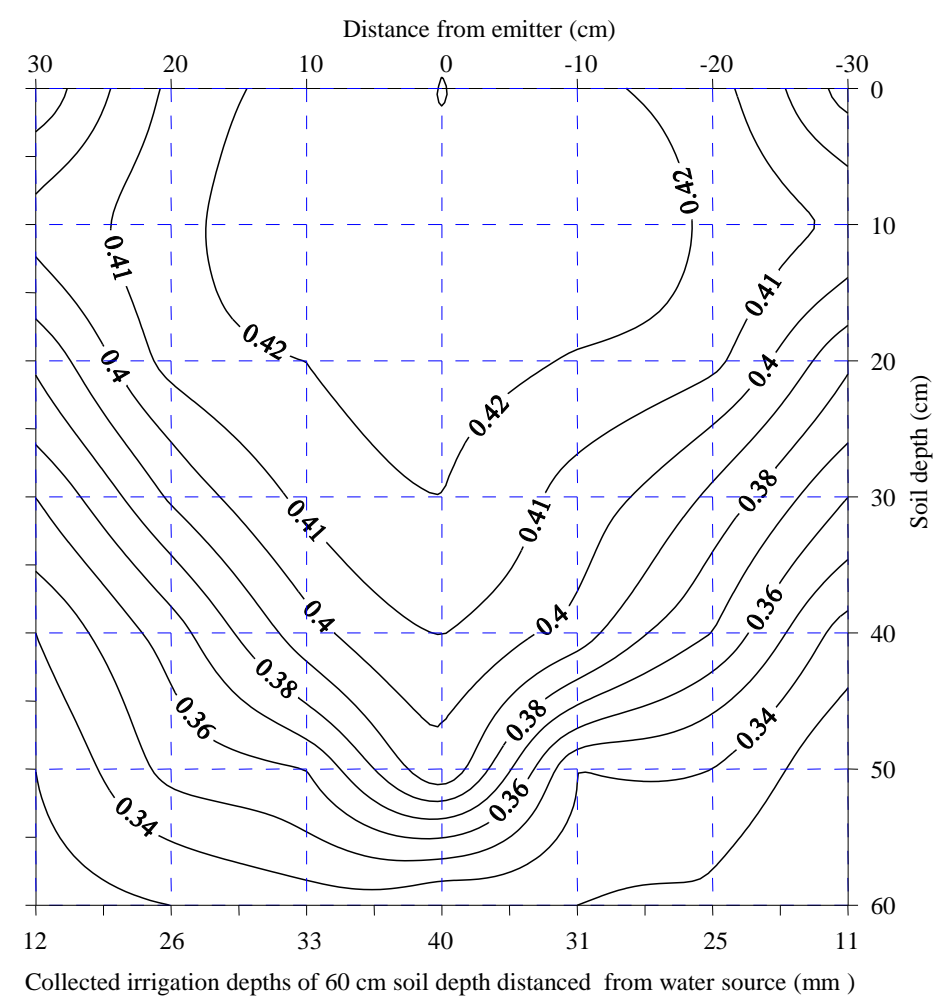

Figure 3. Volumetric moisture content after soil-water redistribution under trickle source with $8 \mathrm{l} / \mathrm{h}$ emitter flow rate and $1 \mathrm{~h}$ flowing. 


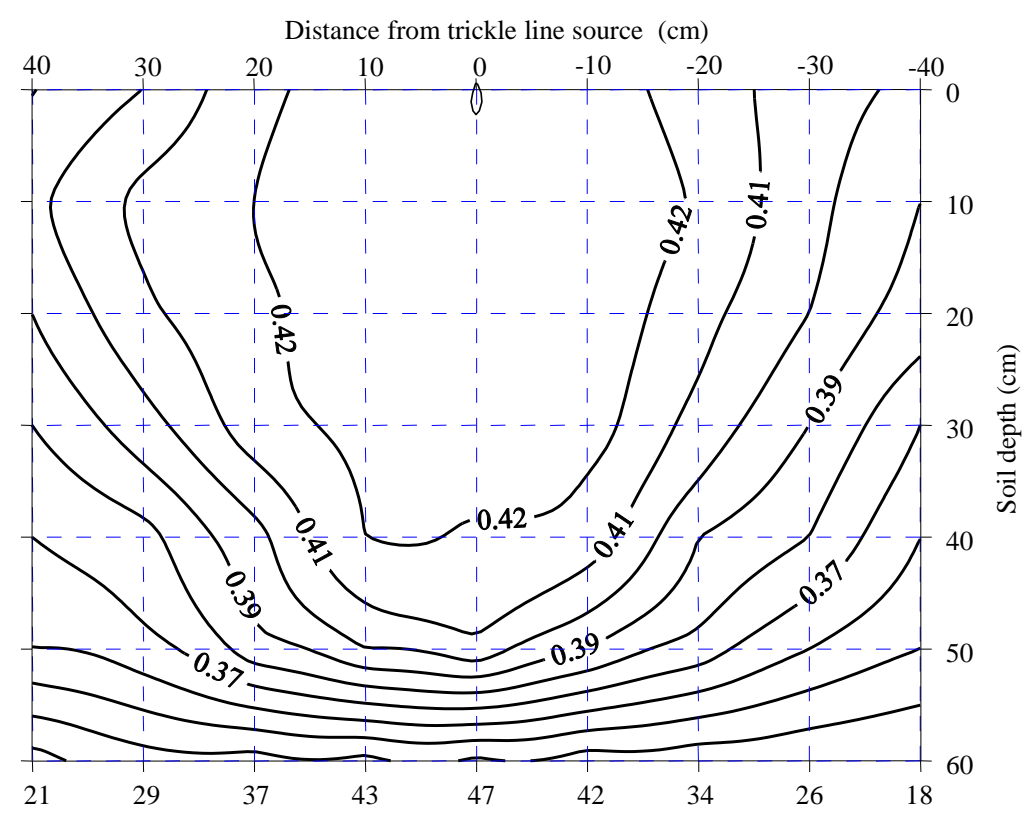

Collected irrigation depths of $60 \mathrm{~cm}$ soil depth ( $\mathrm{mm}$ ) distanced from water source )

Figure 4. Volumetric moisture content after soil-water redistribution under trickle irrigation with $26.6 \mathrm{l} / \mathrm{m} / \mathrm{h}$ trickle line source flow rate and $1.25 \mathrm{~h}$ flowing.

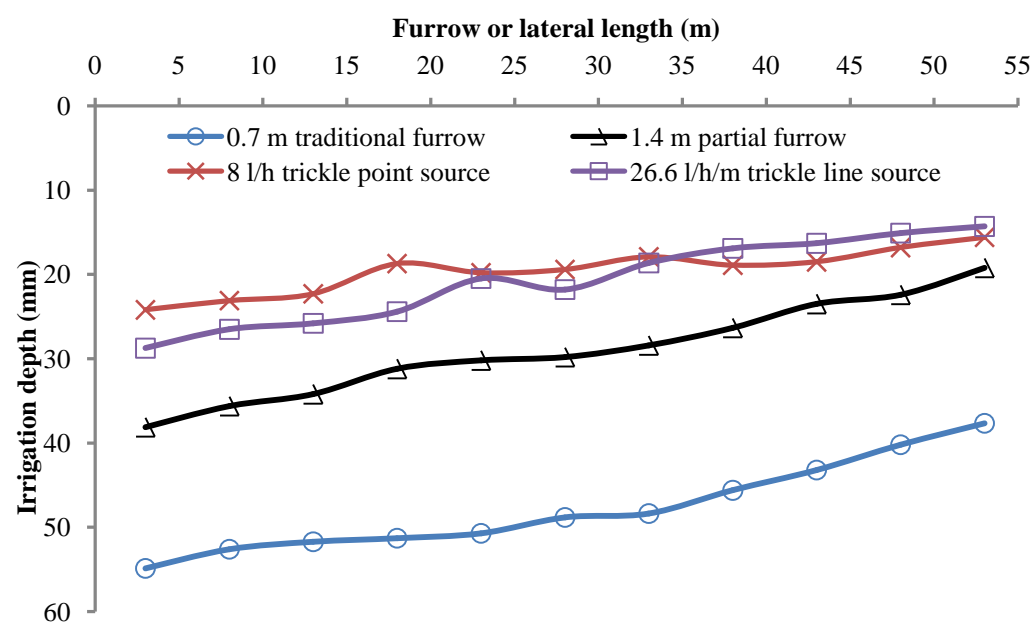

Figure 5. Soil infiltrated water depth along furrow or trickle lateral.

depth $(\mu)$ according to [4] [16] were equal, therefore, excessive water percentage $\left(\mathrm{P}_{\mathrm{S}}\right)$ occurred along the first 33 $\mathrm{m}$ of irrigation line was equal to water deficit percentage $\left(\mathrm{P}_{\mathrm{D}}\right)$ occurred along the last $22 \mathrm{~m}$ of irrigation line. For that case, $P_{S}=P_{D}=0.4312 C V$ using linear distribution developed by [16]. Application $E_{a}$ and storage $E_{s}$ efficiencies were $\mathrm{E}_{\mathrm{a}}=\mathrm{E}_{\mathrm{s}}=1-0.4312 C V$, respectively. They were, respectively, achieved 94.0, 91.4, 94.2, and 89.8\% for TF, PF, TP, and TL methods. TP high value was achieved because emitter was spaced $0.6 \mathrm{~m}$ along trickle lateral compared with $0.3 \mathrm{~m}$ for TL method. For furrow methods, irrigation efficiency was achieved around $90 \%$ which was also high value due to selecting both optimum inlet flow rate $2.4 \mathrm{~m}^{3} \cdot \mathrm{h}^{-1}$ with uniform land slope $0.1 \%$ for smallholding area. Furthermore, inlet water flow was left for 5 minutes storage after water advanced to the block-end furrow. Water saving per irrigation was $39 \%, 59 \%$, and $56 \%$ for PF, TP, and TL methods, respectively, compared with TF method. Regardless of irrigation number in which trickle system was twice that of furrow irrigation, trickle method achieved higher water savings per irrigation. These results were obtained earlier by [1] [2]. 


\subsection{Irrigation Practice and Potato Crop Coefficient}

At a $33^{\text {rd }} \mathrm{m}$ water applied was equal to water use, potato irrigation based on soil water content as shown in Table 2 and Table 3 was scheduled for each interval in both 2014 spring and fall growing seasons. Water use by potato in the fall growing season was $35 \%$ lower compared to the spring growing season. Water saving per season was $28 \%, 18 \%$, and $11 \%$ in spring growing season and $17.5 \%, 11.0 \%$, and $7.0 \%$ in fall for PF, TP, and TL methods compared with TF method, respectively. Seasonal water use was significantly higher by either spring growing season or PF followed by TP, and then TL methods. Potato plants consumed less water under PF followed by TP and TL irrigations, relative to that of TF irrigation, suggesting that high evaporation from wetted soil surface in early growth stages was higher in TF irrigation. Irrigation requirements were significantly increased in spring growing season, relative to those in fall growing season, due to increasing temperature and solar radiation during spring growing season as shown in Table 1. Our results are similar to those recorded by [4], [22]. In both growing seasons, water use by potato was less for partial furrow than for trickle irrigation because irrigation interval for trickle system was half of furrow irrigation interval and both were partially wetted.

For a given $33^{\text {rd }} \mathrm{m}$ treatment, potato crop coefficient $\left(\mathrm{k}_{\mathrm{c}}\right)$ under furrow and trickle irrigation methods was determined as the ratio of actual $\left(\mathrm{ET}_{\mathrm{c}}\right)$ to reference $\left(\mathrm{ET}_{\mathrm{o}}\right)$ evapotranspiration for the 2014 spring and fall growing seasons (Table 2 and Table 3 ). The initial values of $k_{c}$ were significantly reduced under PT, TP, and TL irrigation methods compared with PF in early vegetative stage due to increasing soil water evaporation along traditional furrow line. Crop coefficient in full vegetative stage was less than 1.0 for partial furrow and trickle irrigation methods compared to TF which was significantly higher than 1.0. Values of $\mathrm{k}_{\mathrm{c}}$ decreased during the senescence phase at the end of both growing seasons because of senescing leaves. Seasonal $k_{c}$ values by TF irrigation method compared to other methods were significantly increased due to increasing wetted soil volume where soil water evaporation was enhanced during the season. There was no significant difference in $\mathrm{k}_{\mathrm{c}}$ between seasons. The obtained trend of results are in agreement with those found by [23] [24] working on potato and [4] working on squash.

Table 2. Potato irrigation used, reference evapotranspiration $\left(\mathrm{ET}_{\mathrm{o}}\right)$ and crop coefficient in 2014 spring season.

\begin{tabular}{|c|c|c|c|c|c|c|c|c|c|}
\hline \multirow{3}{*}{ Irrigation or reading date } & \multicolumn{4}{|c|}{ Water use (mm) } & \multirow{3}{*}{$\begin{array}{c}\mathrm{FAO}_{6} \mathrm{ET}_{\mathrm{o}} \\
\mathrm{mm}\end{array}$} & \multicolumn{4}{|c|}{ Crop coefficient $\mathrm{k}_{\mathrm{c}}$} \\
\hline & \multicolumn{2}{|c|}{ Furrow } & \multicolumn{2}{|c|}{ Trickle source } & & \multicolumn{2}{|l|}{ Furrow } & \multicolumn{2}{|c|}{ Trickle source } \\
\hline & Traditional & Partial & Point & Line & & Traditional & Partial & Point & Line \\
\hline 10-Feb & \multicolumn{9}{|c|}{ Applying $56 \mathrm{~mm}$ before potato seeding using surface irrigation } \\
\hline 21-Feb & \multicolumn{4}{|c|}{ Seeding after evaporating $9.6 \mathrm{~mm}$ soil water depth } & 20.34 & 0.47 & 0.47 & 0.47 & 0.47 \\
\hline 11-Mar & 22.20 & 22.20 & 22.20 & 22.20 & 39.70 & 0.56 & 0.56 & 0.56 & 0.56 \\
\hline 24-Mar & 22.20 & 17.34 & 18.69 & 20.57 & 30.60 & 0.73 & 0.57 & 0.61 & 0.67 \\
\hline 4-Apr & 20.50 & 13.18 & 18.27 & 20.35 & 22.17 & 0.92 & 0.59 & 0.82 & 0.92 \\
\hline 11-Apr & 23.40 & 16.12 & 18.69 & 20.35 & 22.30 & 1.05 & 0.72 & 0.84 & 0.91 \\
\hline 17-Apr & 24.60 & 17.04 & 19.32 & 21.03 & 22.70 & 1.08 & 0.75 & 0.85 & 0.93 \\
\hline 23-Apr & 24.00 & 16.43 & 19.32 & 21.03 & 21.80 & 1.10 & 0.75 & 0.89 & 0.96 \\
\hline 29-Apr & 24.60 & 17.04 & 19.32 & 21.03 & 22.10 & 1.11 & 0.77 & 0.87 & 0.95 \\
\hline 5-May & 24.60 & 17.04 & 19.95 & 21.72 & 22.56 & 1.09 & 0.76 & 0.88 & 0.96 \\
\hline 10-May & 22.80 & 15.21 & 18.90 & 20.57 & 19.30 & 1.18 & 0.79 & 0.98 & 1.07 \\
\hline 15-May & 24.00 & 16.73 & 18.90 & 20.57 & 20.70 & 1.16 & 0.81 & 0.91 & 0.99 \\
\hline 20-May & 25.20 & 15.82 & 18.90 & 20.57 & 22.60 & 1.12 & 0.70 & 0.84 & 0.91 \\
\hline 26-May & 25.20 & 17.64 & 18.90 & 20.57 & 25.60 & 0.98 & 0.69 & 0.74 & 0.80 \\
\hline 1-Jun & 24.60 & 15.82 & 18.90 & 20.57 & 25.90 & 0.95 & 0.61 & 0.73 & 0.79 \\
\hline 8-Jun & 20.40 & 17.04 & 18.90 & 20.57 & 30.35 & 0.67 & 0.56 & 0.62 & 0.68 \\
\hline $118 \mathrm{~d}$ & 328.30 & 234.63 & 269.16 & 291.72 & 348.4 & 0.94 & 0.67 & 0.77 & 0.84 \\
\hline
\end{tabular}


Table 3. Potato irrigation used, reference evapotranspiration $\left(\mathrm{ET}_{\mathrm{o}}\right)$ and crop coefficient in 2014 fall season.

\begin{tabular}{|c|c|c|c|c|c|c|c|c|c|}
\hline \multirow{3}{*}{ Irrigation or reading date } & \multicolumn{4}{|c|}{ Water use (mm) } & \multirow{3}{*}{$\frac{\mathrm{FAO}_{6} \mathrm{ET}_{\mathrm{o}}}{\mathrm{mm}}$} & \multicolumn{4}{|c|}{ Crop coefficient $\mathrm{k}_{\mathrm{c}}$} \\
\hline & \multicolumn{2}{|c|}{ Furrow } & \multicolumn{2}{|c|}{ Trickle source } & & \multicolumn{2}{|c|}{ Furrow } & \multicolumn{2}{|c|}{ Trickle source } \\
\hline & Traditional & Partial & Point & Line & & Traditional & Partial & Point & Line \\
\hline 3-Oct & \multicolumn{9}{|c|}{ Applying $51 \mathrm{~mm}$ before potato seeding using surface irrigation } \\
\hline 10-Oct & \multicolumn{4}{|c|}{ Seeding after evaporating $13 \mathrm{~mm}$ soil water depth } & 24.40 & 0.53 & 0.53 & 0.53 & 0.53 \\
\hline 22-Oct & 21.00 & 21.00 & 21.0 & 21.00 & 35.50 & 0.59 & 0.59 & 0.59 & 0.59 \\
\hline 4-Nov & 24.00 & 18.25 & 19.74 & 21.49 & 29.30 & 0.82 & 0.62 & 0.67 & 0.73 \\
\hline $14-\mathrm{Nov}$ & 22.00 & 15.21 & 18.90 & 21.03 & 21.60 & 1.02 & 0.70 & 0.88 & 0.97 \\
\hline $25-\mathrm{Nov}$ & 22.00 & 16.12 & 19.11 & 19.20 & 19.90 & 1.11 & 0.81 & 0.96 & 0.96 \\
\hline 7-Dec & 23.50 & 17.04 & 19.74 & 20.57 & 20.40 & 1.15 & 0.84 & 0.97 & 1.01 \\
\hline 27-Dec & 31.20 & 24.63 & 26.68 & 27.63 & 28.20 & 1.11 & 0.87 & 0.95 & 0.98 \\
\hline 18-Jan & 24.30 & 21.34 & 22.78 & 24.19 & 26.30 & 0.92 & 0.81 & 0.87 & 0.92 \\
\hline 2-Feb & 19.00 & 18.25 & 17.43 & 17.37 & 25.85 & 0.74 & 0.71 & 0.67 & 0.67 \\
\hline $122 \mathrm{~d}$ & 200.00 & 164.83 & 178.38 & 185.49 & 231.45 & 0.89 & 0.72 & 0.79 & 0.82 \\
\hline
\end{tabular}

\subsection{Potato Tuber Crop Response}

Potato crop response was obtained by collecting water uses corresponding to their crop yields at the $3^{\text {rd }}, 13^{\text {th }}$, $23^{\text {rd }}, 33^{\text {rd }}, 43^{\text {rd }}$, and $53^{\text {rd }} \mathrm{m}$ along $55 \mathrm{~m}$ furrow or trickle lateral. Relative potato yield $\mathrm{Y} / \mathrm{Y}_{\mathrm{m}}$ versus ratio of irrigation depth $\mathrm{d} / \mu$ was shown for the 2014 spring and fall growing seasons in Figure 6 and Figure 7, respectively. Potato tuber yield decreased as applied water decreased in deficit irrigation (U43 and U53 treatments) due to plant stress caused by the drier soil. However, potato tuber yield also decreased as irrigation water applied resulted in excessive irrigation (U23, U13 and U3) creating more wetting stress on plant roots, causing more vegetative growth, and potential leaching of nutrients from the root zone. Similar results were obtained by [10], and [9] working on potato [25] working on pepper, [26] working on cucumber, [4] working on squash and [27] working on pumpkin, all of them observed yield was negatively affected by either deficit or excessive irrigation conditions. For a given $33^{\text {rd }}$ scheduled irrigation treatment, maximum yield values $\mathrm{Y}_{\mathrm{m}}$ were achieved 30.761 ,

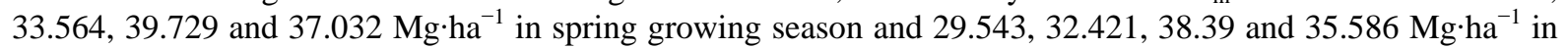
fall growing season under TF, PF, TP and TL methods, respectively. Potato tuber yield was significantly enhanced under trickle irrigation compared with furrow irrigation because irrigation water and fertilizer were uniformly concentrated around plant roots. References [28] working on sugar beet and [4] working on squash with furrow and trickle irrigated reported similar results. In spring growing season, potato tuber yield reduction coefficients $1.82\left(\mathrm{k}_{1}\right.$ with $\left.\mathrm{r}^{2}=0.935\right)$ in deficit and $0.611\left(\mathrm{k}_{2}\right.$ with $\left.\mathrm{r}^{2}=0.805\right)$ in excessive irrigation conditions. In fall growing season, $\mathrm{k}_{1}$ was $1.65\left(\mathrm{r}^{2}=0.963\right)$ and $\mathrm{k}_{2}$ was $0.58\left(\mathrm{r}^{2}=0.748\right)$. This relationship for $\mathrm{k}_{1}$ was not significantly changed by irrigation method or season; however, $\mathrm{k}_{2}$ increased in spring growing season compared with fall. The latter had $11 \mathrm{~mm}$ rainfall which was uniformly distributed into soil root zone of potato plants.

\subsection{Leaf Area Index (LAI) of Potato}

Leaf area indices of potato at mid-growing season were significantly affected by 2014 spring and fall growing seasons, irrigation method, and water uniformity along furrow or trickle lateral (Table 4 and Table 5). Vegetative growth was larger during fall that had less radiation and shorter day lengths compared to the spring planting. Reference [29] also reported similar findings earlier. LAI had the greatest increase under trickle irrigation compared with furrow irrigation. Similar results were obtained by [30] working on tomato. Leaf area index at full growth differences were significant between the two growing seasons since there was less solar radiation in fall compared to spring (Table 4). LAI showed significant differences among irrigation method and applications at 5\% level (Table 4 and Table 5). Interaction between irrigation method I and irrigation application U along irrigation line were found for LAI values (Table 5). For a given irrigation method in fall growing season, the highest LAI's were obtained when water was excessively applied (U3, U13 and U23 treatments). These results are in agreement with those of [9] [10] [31] working on potato. 


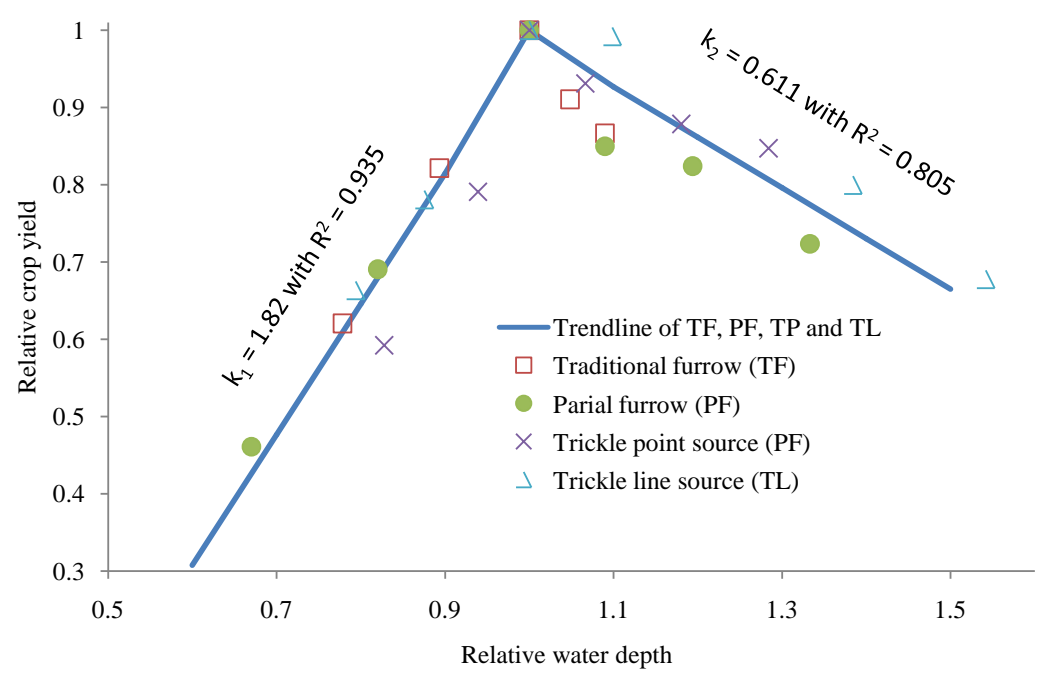

Figure 6. Potato crop response in spring growing season.

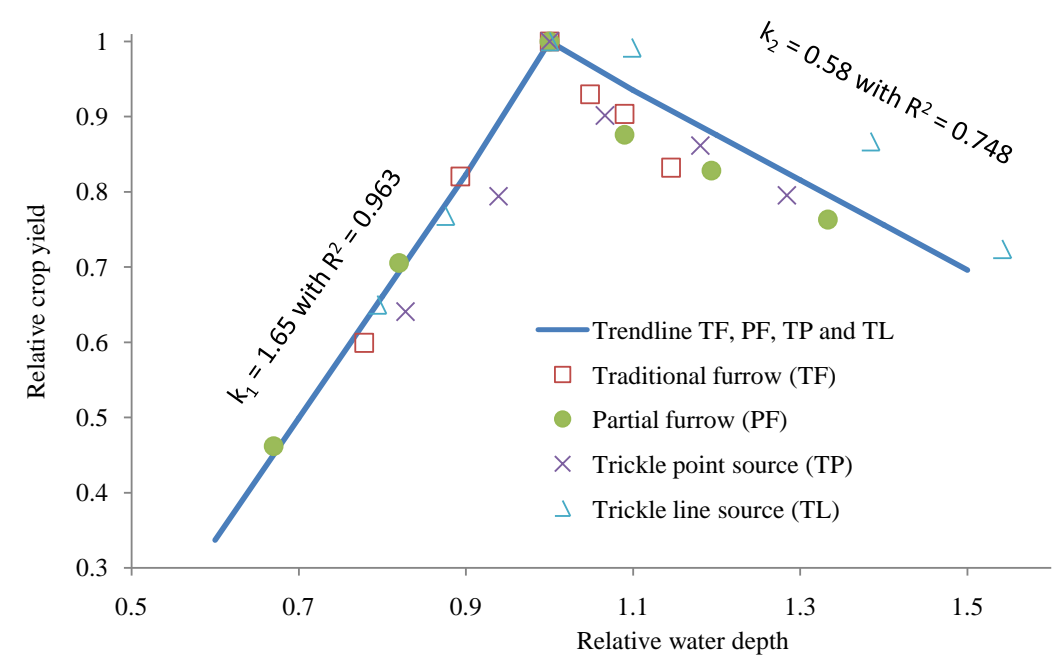

Figure 7. Potato crop response in fall growing season.

\subsection{Potato Tuber Yield, Harvest Index and Total Soluble Solid}

Potato tuber yield, total soluble solid TSS and harvest index HI showed significant differences between spring and fall growing seasons (Table 4 and Table 5). Tuber yield were higher in fall growing season in comparison to the spring growing season. In 2014 fall growing season, average temperature $T_{a}$ and total solar radiation $R_{s}$ began, respectively, with $26.7^{\circ} \mathrm{C}$ and $19.7 \mathrm{MJ} \cdot \mathrm{m}^{-2} \cdot \mathrm{d}^{-1}$ at early growth stages, $20.4^{\circ} \mathrm{C}$ and $13.5 \mathrm{MJ} \cdot \mathrm{m}^{-2} \cdot \mathrm{d}^{-1}$ at full growth vegetative and $16.7^{\circ} \mathrm{C}$ and $9.7 \mathrm{MJ} \cdot \mathrm{m}^{-2} \cdot \mathrm{d}^{-1}$ at maturity growth. In spring growing season, $\mathrm{T}_{\mathrm{a}}$ and $\mathrm{R}_{\mathrm{s}}$ were, respectively, $13.4^{\circ} \mathrm{C}$ and $10.9 \mathrm{MJ} \cdot \mathrm{m}^{-2} \cdot \mathrm{d}^{-1}$ at early growth stage, $14.4^{\circ} \mathrm{C}$ and $15.1 \mathrm{MJ} \cdot \mathrm{m}^{-2} \cdot \mathrm{d}^{-1}$ during full growth and $22.3^{\circ} \mathrm{C}$ and $21.4 \mathrm{MJ} \cdot \mathrm{m}^{-2} \cdot \mathrm{d}^{-1}$ during maturity growth. Decreases in $\mathrm{T}_{\mathrm{a}}$ and $\mathrm{R}_{\mathrm{s}}$ at the end of fall season had no impact because tubers were already filled. On the other hand, $T_{s}$ and $R_{s}$ were lower in early and mid-spring growing season. Our results are in agreement with those obtained by [32] who stated that higher yield was obtained due to better temperature conditions and solar radiation. Maximum fruit yield $\left(30.39 \mathrm{Mg} \cdot \mathrm{h}^{-1}\right)$ and TSS (207.71 g) were obtained for TP method as shown in Table 4, but maximum HI (70.96\%) occurred for TL method and even that had no significant difference with HI obtained by TF, PF, and TP methods. Therefore, trickle irrigation was recommended under selected location along plant row and growing season. Moreover, tuber yield, $\mathrm{HI}$ and TSS were significantly affected by irrigation method I, irrigation application U along furrow or trickle lateral, and their interaction I* U, except HI was not affected by irrigation method. Except for TSS and HI other 
Table 4. Means and standard errors for fresh yield, harvest index (HI), plant dry matter and its components (TSS), and leaf area index (LAI).

\begin{tabular}{|c|c|c|c|c|}
\hline \multirow[b]{2}{*}{ Items } & \multicolumn{4}{|c|}{ Mean \pm SE } \\
\hline & Yield $\left(\mathrm{Mg} \cdot \mathrm{ha}^{-1}\right)$ & HI (\%) & TSS (g) & $\mathrm{LAI}\left(\mathrm{m}^{3} \cdot \mathrm{m}^{-3}\right)$ \\
\hline \multicolumn{5}{|l|}{ Season } \\
\hline Spring & $24.85 \pm 0.26^{\mathrm{A} \dagger}$ & $72.17 \pm 0.35^{\mathrm{B}}$ & $172.73 \pm 1.43^{\mathrm{A}}$ & $2.92 \pm 0.03^{\mathrm{A}}$ \\
\hline Fall & $27.28 \pm 0.26^{\mathrm{B}}$ & $69.13 \pm 0.35^{\mathrm{A}}$ & $193.49 \pm 0.43^{\mathrm{B}}$ & $3.84 \pm 0.03^{\mathrm{B}}$ \\
\hline \multicolumn{5}{|c|}{ Irrigation method (I) } \\
\hline $\mathrm{TF}$ & $21.31 \pm 0.36^{\mathrm{A}}$ & $70.05 \pm 2.02^{\mathrm{A}}$ & $155.97 \pm 0.49^{\mathrm{A}}$ & $3.13 \pm 0.05^{\mathrm{A}}$ \\
\hline $\mathrm{PF}$ & $23.69 \pm 0.36^{\mathrm{B}}$ & $70.71 \pm 2.02^{\mathrm{A}}$ & $172.67 \pm 0.49^{\mathrm{B}}$ & $3.17 \pm 0.05^{\mathrm{B}}$ \\
\hline TP & $30.39 \pm 0.36^{\mathrm{D}}$ & $70.87 \pm 2.02^{\mathrm{A}}$ & $207.71 \pm 0.49^{\mathrm{D}}$ & $3.72 \pm 0.05^{\mathrm{D}}$ \\
\hline $\mathrm{TL}$ & $28.89 \pm 0.36^{\mathrm{C}}$ & $70.96 \pm 2.02^{\mathrm{A}}$ & $196.08 \pm 0.49^{\mathrm{C}}$ & $3.49 \pm 0.05^{\mathrm{C}}$ \\
\hline \multicolumn{5}{|c|}{ Non-uniform depth (U) } \\
\hline U3 & $23.08 \pm 0.44^{\mathrm{B}}$ & $69.46 \pm 0.60^{\mathrm{A}}$ & $166.28 \pm 0.60^{\mathrm{B}}$ & $3.36 \pm 0.06^{\mathrm{C}}$ \\
\hline U13 & $26.57 \pm 0.44^{\mathrm{D}}$ & $69.12 \pm 0.60^{\mathrm{A}}$ & $183.32 \pm 0.60^{\mathrm{D}}$ & $3.61 \pm 0.06^{\mathrm{D}}$ \\
\hline U23 & $29.33 \pm 0.44^{\mathrm{E}}$ & $69.39 \pm 0.60^{\mathrm{A}}$ & $203.56 \pm 0.60^{\mathrm{E}}$ & $3.98 \pm 0.06^{\mathrm{F}}$ \\
\hline U33 & $33.26 \pm 0.44^{\mathrm{F}}$ & $72.37 \pm 0.60^{\mathrm{B}}$ & $219.91 \pm 0.60^{\mathrm{F}}$ & $3.67 \pm 0.06^{\mathrm{E}}$ \\
\hline U43 & $25.26 \pm 0.44^{\mathrm{C}}$ & $72.21 \pm 0.60^{\mathrm{B}}$ & $180.53 \pm 0.60^{\mathrm{C}}$ & $3.11 \pm 0.06^{\mathrm{B}}$ \\
\hline U53 & $18.91 \pm 0.44^{\mathrm{A}}$ & $71.36 \pm 0.60^{\mathrm{B}}$ & $145.05 \pm 0.60^{\mathrm{A}}$ & $2.55 \pm 0.06^{\mathrm{A}}$ \\
\hline
\end{tabular}

${ }^{\dagger}$ Treatment means with the same letter are not significant at the $\mathrm{p} \leq 0.05$ level.

Table 5. Mean square, F value, and probability for fresh yield, harvest index (HI), plant dry matter and its components (TSS), and leaf area index (LAI).

\begin{tabular}{|c|c|c|c|c|c|c|c|c|c|}
\hline \multirow[b]{2}{*}{ Items } & \multirow[b]{2}{*}{$\mathrm{df}$} & \multicolumn{4}{|c|}{ Mean Square } & \multicolumn{4}{|c|}{ F Value and Probability ${ }^{\dagger}$} \\
\hline & & 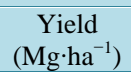 & $\begin{array}{l}\mathrm{HI} \\
(\%)\end{array}$ & $\begin{array}{l}\text { TSS } \\
\text { (g) }\end{array}$ & $\begin{array}{c}\text { LAI } \\
\left(\mathrm{m}^{3} \cdot \mathrm{m}^{-3}\right)\end{array}$ & 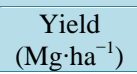 & $\begin{array}{l}\text { HI } \\
(\%)\end{array}$ & $\begin{array}{l}\text { TSS } \\
\text { (g) }\end{array}$ & $\begin{array}{c}\text { LAI } \\
\left(\mathrm{m}^{3} \cdot \mathrm{m}^{-3}\right)\end{array}$ \\
\hline Season (S) & 1 & 212.7 & 331.3 & 15510.8 & 30.39 & $45.29 *^{\dagger}$ & $38.51^{*}$ & $105.20 *$ & $394.16^{*}$ \\
\hline Irrigation (I) & 3 & 660.1 & 6.0 & 19423.5 & 2.84 & $140.57^{*}$ & $0.70^{\mathrm{ns}}$ & $131.74 *$ & $36.78^{*}$ \\
\hline $\begin{array}{l}\text { Non-uniform } \\
\text { depth (U) }\end{array}$ & 5 & 592.8 & 54.0 & 16850.3 & 6.02 & $126.23 *$ & $6.28 *$ & $114.28 *$ & $78.04 *$ \\
\hline $\mathrm{S} * \mathrm{I}$ & 3 & 6.2 & 38.9 & 474.4 & 0.19 & $1.33^{\mathrm{ns}}$ & $4.52 *$ & $3.22 *$ & $2.48^{\mathrm{ns}}$ \\
\hline $\mathrm{S} * \mathrm{U}$ & 5 & 7.3 & 20.0 & 77.8 & 0.02 & $1.56^{\mathrm{ns}}$ & $2.32 *$ & $0.53^{\mathrm{ns}}$ & $0.22^{\mathrm{ns}}$ \\
\hline $\mathrm{I} * \mathrm{U}$ & 15 & 31.9 & 25.9 & 607.8 & 0.33 & $6.80^{*}$ & $3.01 *$ & $4.12 *$ & $4.30^{*}$ \\
\hline $\mathrm{S} * \mathrm{I} * \mathrm{U}$ & 15 & 2.6 & 7.9 & 85.1 & 0.04 & $0.55^{\mathrm{ns}}$ & $0.92^{\mathrm{ns}}$ & $0.58^{\mathrm{ns}}$ & $0.54^{\mathrm{ns}}$ \\
\hline Exp. error & 96 & 4.7 & 8.6 & 147.4 & 0.08 & & & & \\
\hline
\end{tabular}

${ }^{t_{*}}$ is significant at the $\mathrm{p} \leq 0.05$ level and ns is nonsignificant.

observed parameters showed a significant interaction between season and irrigation method S * I (Table 5). Except for HI by $\mathrm{S} * \mathrm{U}$ interaction, no significant differences occurred between variables in Table 4. Results are in agreement with those obtained by [33], working on potato, found that tuber yield and plant dry matter were significantly affected by irrigation regimes. [8] [17] [34] [35], working on potato, found that potato yield and yield components were significantly changed by growing season, irrigation method and regimes.

\subsection{Potato Tuber Quality}

Potato tuber weight (g), number, and marketing yield (\%) and culls (\%) were statistically analyzed as shown in Table 6 and Table 7. For given irrigation method and applications (Table 6), tuber weight in fall growing season (116.3 g) were higher relative to that in spring growing season (88.41 g). Tuber number was higher in spring compared with fall growing season. Marketable yield, as well as culls, was not significantly affected by season, 
Table 6. Means and standard errors for potato tuber weight, tuber number of 6 plants, and grading.

\begin{tabular}{|c|c|c|c|c|c|c|}
\hline \multirow{3}{*}{ Item } & \multicolumn{6}{|c|}{ Mean \pm SE } \\
\hline & \multirow{2}{*}{$\begin{array}{l}\text { Single tuber } \\
\text { weight (g) }\end{array}$} & \multirow{2}{*}{$\begin{array}{c}\text { Tuber No of } 6 \\
\text { plants }\end{array}$} & \multicolumn{3}{|c|}{ Marketable yield percentage, \% } & \multirow{2}{*}{$\begin{array}{l}\text { Cull, \% } \\
(\geq 50 \mathrm{~g})\end{array}$} \\
\hline & & & Large ( $\geq 150 \mathrm{~g})$ & $\begin{array}{l}\text { Medium }(150 \mathrm{~g} \geq \\
\mathrm{W} \leq 100 \mathrm{~g})\end{array}$ & $\begin{array}{c}\text { Small } \\
(100 \mathrm{~W} \leq 50 \mathrm{~g})\end{array}$ & \\
\hline \multicolumn{7}{|l|}{ Season } \\
\hline Spring & $88.41 \pm 1.04^{\mathrm{A} \dagger}$ & $34.81 \pm 0.3^{\mathrm{B}}$ & $30.12 \pm 0.5^{\mathrm{B}}$ & $26.94 \pm 0.63^{\mathrm{A}}$ & $27.93 \pm 0.6^{\mathrm{A}}$ & $15.01 \pm 0.67^{\mathrm{A}}$ \\
\hline Fall & $116.27 \pm 1.04^{\mathrm{B}}$ & $29.56 \pm 0.3^{\mathrm{A}}$ & $27.01 \pm 0.5^{\mathrm{A}}$ & $28.19 \pm 0.63^{\mathrm{A}}$ & $29.69 \pm 0.6^{\mathrm{B}}$ & $15.11 \pm 0.67^{\mathrm{A}}$ \\
\hline \multicolumn{7}{|c|}{ Irrigation method (I) } \\
\hline $\mathrm{TF}$ & $100.67 \pm 1.47^{\mathrm{B}}$ & $27.39 \pm 0.43^{\mathrm{B}}$ & $27.82 \pm 0.73^{\mathrm{B}}$ & $26.37 \pm 0.89^{\mathrm{A}}$ & $27.70 \pm 0.85^{\mathrm{A}}$ & $18.12 \pm 0.95^{\mathrm{B}}$ \\
\hline $\mathrm{PF}$ & $89.94 \pm 1.47^{\mathrm{A}}$ & $25.37 \pm 0.43^{\mathrm{A}}$ & $25.37 \pm 0.73^{\mathrm{A}}$ & $29.69 \pm 0.89^{\mathrm{B}}$ & $30.64 \pm 0.85^{\mathrm{B}}$ & $14.31 \pm 0.95^{\mathrm{A}}$ \\
\hline $\mathrm{TP}$ & $103.43 \pm 1.47^{\mathrm{C}}$ & $36.42 \pm 0.43^{\mathrm{D}}$ & $30.73 \pm 0.73^{\mathrm{C}}$ & $28.32 \pm 0.89^{\mathrm{AB}}$ & $26.77 \pm 0.85^{\mathrm{A}}$ & $14.17 \pm 0.95^{\mathrm{A}}$ \\
\hline $\mathrm{TL}$ & $115.31 \pm 1.47^{\mathrm{D}}$ & $31.92 \pm 0.43^{\mathrm{C}}$ & $30.35 \pm 0.73^{\mathrm{C}}$ & $25.87 \pm 0.89^{A}$ & $30.14 \pm 0.85^{\mathrm{B}}$ & $13.65 \pm 0.95^{\mathrm{A}}$ \\
\hline \multicolumn{7}{|c|}{ Non-uniform depth (U) } \\
\hline U3 & $97.26 \pm 1.8^{\mathrm{A}}$ & $29.79 \pm 0.53^{\mathrm{B}}$ & $23.86 \pm 0.89^{\mathrm{A}}$ & $26.03 \pm 1.09^{\mathrm{B}}$ & $27.50 \pm 1.04^{\mathrm{ABC}}$ & $22.61 \pm 1.16^{\mathrm{C}}$ \\
\hline $\mathrm{U} 13$ & $102.47 \pm 1.8^{\mathrm{B}}$ & $32.58 \pm 0.53^{\mathrm{C}}$ & $27.17 \pm 0.89^{\mathrm{B}}$ & $28.25 \pm 1.09^{\mathrm{BC}}$ & $26.73 \pm 1.04^{\mathrm{AB}}$ & $17.86 \pm 1.16^{\mathrm{B}}$ \\
\hline U23 & $104.52 \pm 1.8^{\mathrm{C}}$ & $35.29 \pm 0.53^{\mathrm{D}}$ & $31.65 \pm 0.89^{\mathrm{C}}$ & $31.19 \pm 1.09^{\mathrm{C}}$ & $26.47 \pm 1.04^{\mathrm{A}}$ & $10.69 \pm 1.16^{\mathrm{A}}$ \\
\hline U33 & $105.48 \pm 1.8^{\mathrm{C}}$ & $39.79 \pm 0.53^{\mathrm{E}}$ & $31.51 \pm 0.89^{\mathrm{C}}$ & $29.77 \pm 1.09^{\mathrm{C}}$ & $30.43 \pm 1.04^{\mathrm{CD}}$ & $8.30 \pm 1.16^{\mathrm{A}}$ \\
\hline U43 & $101.46 \pm 1.8^{\mathrm{B}}$ & $31.79 \pm 0.53^{\mathrm{C}}$ & $30.13 \pm 0.89^{\mathrm{C}}$ & $28.03 \pm 1.09^{\mathrm{BC}}$ & $32.09 \pm 1.04^{\mathrm{D}}$ & $9.76 \pm 1.16^{\mathrm{A}}$ \\
\hline U53 & $102.83 \pm 1.8^{\mathrm{B}}$ & $23.83 \pm 0.53^{\mathrm{A}}$ & $27.07 \pm 0.89^{\mathrm{B}}$ & $22.12 \pm 1.09^{\mathrm{A}}$ & $29.65 \pm 1.04^{\mathrm{BCD}}$ & $21.16 \pm 1.16^{\mathrm{C}}$ \\
\hline
\end{tabular}

${ }^{\dagger}$ Treatment means with the same letter are not significant at the $\mathrm{p} \leq 0.05$ level.

Table 7. Mean square, F value, and probability for potato tuber weight, number of 6 plants, and grading.

\begin{tabular}{|c|c|c|c|c|c|c|c|}
\hline & \multirow[b]{2}{*}{ df } & \multicolumn{6}{|c|}{ Mean Square } \\
\hline & & $\begin{array}{l}\text { Single tuber } \\
\text { weight, W } \\
\text { (g) }\end{array}$ & $\begin{array}{l}\text { Tuber No } \\
\text { of } 6 \text { plants }\end{array}$ & $\begin{array}{l}\text { Large, \% } \\
(\geq 150 \mathrm{~g})\end{array}$ & $\begin{array}{c}\text { Medium, \% } \\
(150 \mathrm{~g} \geq \mathrm{W} \leq \\
100 \mathrm{~g})\end{array}$ & $\begin{array}{c}\text { Small, \% } \\
(100 \mathrm{~g} \geq \\
\mathrm{W} \leq 50 \mathrm{~g})\end{array}$ & $\begin{array}{l}\text { Cull, \% } \\
(\geq 50 \mathrm{~g})\end{array}$ \\
\hline Season (S) & 1 & 108043.7 & 506.25 & 346.80 & 56.30 & 111.65 & 0.30 \\
\hline Irrigation (I) & 3 & 2248.43 & 366.32 & 223.90 & 112.54 & 126.12 & 152.45 \\
\hline $\begin{array}{l}\text { Non-uniform } \\
\text { depth (U) }\end{array}$ & 5 & 291.52 & 521.23 & 225.42 & 242.89 & 122.78 & 935.66 \\
\hline $\mathrm{S} * \mathrm{I}$ & 3 & 167.63 & 1.29 & 21.61 & 5.34 & 4.30 & 20.06 \\
\hline $\mathrm{S} * \mathrm{U}$ & 5 & 158.63 & 1.05 & 2.30 & 6.53 & 4.15 & 3.03 \\
\hline $\mathrm{I} * \mathrm{U}$ & 15 & 688.05 & 47.35 & 158.27 & 164.96 & 192.94 & 79.44 \\
\hline $\mathrm{S} * \mathrm{I} * \mathrm{U}$ & 15 & 67.54 & 1.60 & 7.12 & 4.06 & 4.31 & 7.74 \\
\hline \multirow[t]{2}{*}{ Error } & 96 & 77.55 & 6.69 & 18.94 & 28.74 & 26.07 & 32.27 \\
\hline & & \multicolumn{6}{|c|}{ F-value } \\
\hline Season (S) & 1 & $1393.17 *$ & $75.62 *$ & $18.31^{*}$ & $1.959^{\mathrm{ns}}$ & $4.283^{*}$ & $0.009^{\text {ns }}$ \\
\hline Irrigation (I) & 3 & $28.992 *$ & $54.721^{*}$ & $11.82^{*}$ & $3.916^{*}$ & $4.837 *$ & $4.73^{*}$ \\
\hline $\begin{array}{c}\text { Non-uniform } \\
\text { depth (U) }\end{array}$ & 5 & $3.67^{*}$ & $77.86^{*}$ & $11.90^{*}$ & $8.453^{*}$ & $4.71^{*}$ & $29.00 *$ \\
\hline $\mathrm{S}^{*} \mathrm{I}$ & 3 & $2.16^{\mathrm{ns}}$ & $0.19^{\mathrm{ns}}$ & $1.14^{\mathrm{ns}}$ & $0.19^{\text {ns }}$ & $0.17^{\mathrm{ns}}$ & $0.62^{\mathrm{ns}}$ \\
\hline $\mathrm{S} * \mathrm{U}$ & 5 & $2.045^{\mathrm{ns}}$ & $0.16^{\mathrm{ns}}$ & $0.12^{\mathrm{ns}}$ & $0.23^{\text {ns }}$ & $0.16^{\mathrm{ns}}$ & $0.09^{\mathrm{ns}}$ \\
\hline $\mathrm{I} * \mathrm{U}$ & 15 & $8.87 *$ & $7.07^{*}$ & $8.36^{*}$ & $5.74^{*}$ & $7.40^{*}$ & $2.46^{*}$ \\
\hline $\mathrm{S} * \mathrm{I} * \mathrm{U}$ & 15 & $0.87^{\mathrm{ns}}$ & $0.24^{\mathrm{ns}}$ & $0.38^{\mathrm{ns}}$ & $0.14^{\mathrm{ns}}$ & $0.17^{\mathrm{ns}}$ & $0.24^{\mathrm{ns}}$ \\
\hline
\end{tabular}

\footnotetext{
${ }^{\dagger} *$ Significant at the $\mathrm{p} \leq 0.05$ level. $\mathrm{ns}=$ nonsignificant.
} 
except large and small tubers. Trickle line source followed by trickle point and partial furrow irrigation methods compared with traditional furrow achieved the highest tuber weight with marketable yield and less culls (Table 6). Higher tuber weight, number and marketable yield with fewer culls were produced with U33 treatment which was adequately watered. They were significantly affected by season, irrigation method I, irrigation application U and $\mathrm{I} * \mathrm{U}$ interaction, except tuber medium size (150 $\mathrm{g} \geq \mathrm{W} \leq 100 \mathrm{~g})$ and culls $(\geq 50 \mathrm{~g})$ were not by season (Table 7). No significant differences for Year * I, Year * U and Year * I * U interactions between treatments were found (Table 7). These results are in accordance with those obtained by [8] [12] [17], working on potato, found that tuber growth, number, marketable yield and culls were significantly affected by season, irrigation methods and high water applied. Comparing potato with other vegetables, [30], working on tomato, found that fruit weight and number increased under trickle method compared with furrow method. Reference [36] found that fruit weight and diameter significantly affected by irrigation quantity under trickle irrigation. Reference [22] observed yield, marketable yield and fruit weight and number of squash were significantly higher due to higher solar radiation and temperature. Reference [37] observed that cooler temperatures reduced total yield and number of watermelon.

\section{Conclusions}

For a $33^{\text {rd }} \mathrm{m}$ treatment (U33), wetted soil patterns after soil-water redistribution and optimal irrigation scheduling for potato crop were found under traditional furrow TF, 1-dimensional soil water flow, partial furrow PF, 2dimensional, trickle point source TP, 3-dimensional and trickle line source TL, and 2-dimensional irrigation methods. Wetted soil area fraction $P$ decreased as wetted soil area relative to plant used area decreased. Water saving per season was highly achieved in fall growing season compared with that occurred in spring for PF, TP and TL methods, relative to TF method. Potato crop coefficient was significantly reduced under PF, TP and TL methods compared with TF in most stages due to increasing evaporation from wetted soil surface. In non-uniformity of irrigation applications, potato grown in 2014 fall season achieved higher tuber yield (8.9\%) more than that grown in spring. Tuber yield was significantly $10.0 \%, 29.9 \%$ and $26.2 \%$ higher by PF, TP and TL relative to that obtained by TF, respectively.

For a given irrigation method, potato crop reduction occurred by either deficit (U43 and U53) or excessive (U3, U13 and U23) irrigation applications into the root zone more than optimum water use (U33) by plants. Potato reduction coefficients $\mathrm{k}_{1}$ and $\mathrm{k}_{2}$ were averaged as 1.74 and 0.595 ; both values were not significantly changed by irrigation method or season. Potato yield and its components showed significant $(\mathrm{P}<0.05)$ differences between growing seasons $\mathrm{S}$, among irrigation methods $\mathrm{I}$, among irrigation applications $\mathrm{U}$ and by $\mathrm{I} * \mathrm{U}$ interaction for most potato variables studied, except for harvest index by I and tuber medium size and culls by S. However, differences for the interaction between S and I were only found for HI and TSS. Potato tuber yield and marketable yield were significantly higher by fall growing season, TP and U33.

Based on these results, TP irrigation method was recommended under selected season in non-uniform irrigation condition. Moreover, potato tuber yields and their irrigation depths were measured to figure potato reduction coefficients out; therefore, irrigation management could be optimized in non-uniformity of irrigation conditions based on studies presented by [4] [16]. Furthermore, it is essential that the field be irrigated by a system applying water more uniformly, frequently enough and in sufficient amounts so that the soil never becomes too dry or too wet, taking into consideration the soil water holding capacity and the depth of the potato root zone because both deficit and excessive irrigation have clear negative consequences on yield and grade.

\section{Acknowledgements}

The writers would like to thank the Egyptian Cultural Affairs \& Missions Sector, Egyptian Cultural and Educational Bureau at Washington DC, and USDA-ARS National Laboratory for Agriculture and the Environment at Ames, IA for their cooperation to fund and contribute greatly to do this work.

\section{References}

[1] Wu, I.P. and Gitlin, H.M. (1975) Irrigation Efficiencies of Surface, Sprinkler and Drip Irrigation. Proceedings Second World Congress, International Water Resources Association, New Delhi, 191-199. (Reprinted)

[2] Al-Jamal, M.S., Ball, S. and Sammis, T.W. (2001) Comparison of Sprinkler, Trickle and Furrow Irrigation Efficiencies 
for Onion Production. Agricultural Water Management, 46, 253-266.

http://dx.doi.org/10.1016/S0378-3774(00)00089-5

[3] Amer, K.H. (2009) The Possibility of Improving Surface Irrigation with Blocked End in Sparse Grape Trees. Misr Journal of Agricultural Engineering, 26, 836-862.

[4] Amer, K.H. (2011) Effect of Irrigation Method and Quantity on Squash Yield and Quality. Agricultural Water Management, 98, 1197-1206. http://dx.doi.org/10.1016/j.agwat.2011.03.003

[5] Schwartzman, M. and Zur, B. (1986) Emitter Spacing and Geometry of Wetted Soil Volume. Journal of Irrigation and Drainage Engineering, 112, 242-253. http://dx.doi.org/10.1061/(ASCE)0733-9437(1986)112:3(242)

[6] Zur, B. (1996) Wetted Soil Volume as a Design Objective in Trickle Irrigation. Irrigation Science, 16, 101-115. http://dx.doi.org/10.1007/BF02215617

[7] Singh, V.P., He, Y.C. and Yu, F.X. (1987) 1-D, 2-D and 3-D Infiltration for Irrigation. Journal of Irrigation and Drainage Engineering, 113, 266-278. http://dx.doi.org/10.1061/(ASCE)0733-9437(1987)113:2(266)

[8] Onder, S., Caliskan, M.E., Onder, D. and Caliskan, S. (2005) Different Irrigation Methods and Water Stress Effects on Potato Yield and Yield Components. Agricultural Water Management, 73, 73-86. http://dx.doi.org/10.1016/j.agwat.2004.09.023

[9] Shock, C.C. (2007) The Canon of Potato Science: Irrigation. Potato Research, 50, 331-333. http://dx.doi.org/10.1007/s11540-008-9072-7

[10] Pereira, A.B. and Shock, C.C. (2006) Development of Irrigation Best Management Practices for Potato from a Research Perspective in the United States. Sakia.org E-Publish, 1, 1-20

[11] Satchithanantham, S., Krahn, V., Ranjan, R. and Sager, S. (2014) Shallow Groundwater Uptake and Irrigation Water Redistribution within the Potato Root Zones. Agricultural Water Management, 132, 101-110. http://dx.doi.org/10.1016/j.agwat.2013.10.011

[12] Wang, F., Kang, Y. and Liu, S. (2006) Effects of Drip Irrigation Frequency on Soil Wetting Pattern and Potato Growth in North China Plain. Agricultural Water Management, 79, 248-264. http://dx.doi.org/10.1016/j.agwat.2005.02.016

[13] Patel, N. and Rajput, T.B.S. (2007) Effect of Drip Tape Placement Depth and Irrigation Level on Yield of Potato. Agricultural Water Management, 88, 209-223. http://dx.doi.org/10.1016/j.agwat.2006.10.017

[14] Badr, M.H., El-Tohamy, W.A. and Zaghloul, A.M. (2012) Yield and Water Use Efficiency of Potato Grown under Different Irrigation and Nitrogen Levels in an Arid Region. Agricultural Water Management, 110, 9-15. http://dx.doi.org/10.1016/j.agwat.2012.03.008

[15] Richard, M., Jose, A., Mark, G. and Keith, M. (2002) Spring Squash Production in California. Vegetable Research and Information Center, Vegetable Reproduction Series, California, Publication 7245.

[16] Amer, K.H. (2010) Corn Crop Response under Managing Different Irrigation and Salinity Levels. Agricultural Water Management, 97, 1553-1663. http://dx.doi.org/10.1016/j.agwat.2010.05.010

[17] Sahebi, F.G., Ejlali, F., Ramezani, M. and Pourkhiz, I. (2013) Comparison of Tape Drip Irrigation and Furrow Irrigation Systems on Base of Water Use Efficiency and Yield of Potato in West of Iran. International Journal of Biology, 5, 52-62.

[18] Allen, R.G, Pereira, L.S., Raes, D. and Smith, M. (1998) Crop Evapotranspiration Guidelines for Computing Crop Water Requirements. FAO Irrigation and Drainage Paper 56, United Nations, Rome, 30-42.

[19] Amer, K.H. and Hatfield, J.L. (2004) Canopy Resistance as Affected by Soil and Meteorological Parameters in Potato. Agronomy Journal, 96, 978-985. http://dx.doi.org/10.2134/agronj2004.0978

[20] Wang, F., Kang, Y. and Liu, S. (2006) Effects of Drip Irrigation Frequency on Soil Wetting Pattern and Potato Growth in North China Plain. Agricultural Water Management, 79, 248-264. http://dx.doi.org/10.1016/j.agwat.2005.02.016

[21] Statistical Analysis System (SAS) (2003) User’s Guide. SAS, Carry, North Carolina.

[22] Rouphael, Y. and Colla, G. (2005) Growth, Yield, Fruit Quality and Nutrient Uptake of Hydroponically Cultivated Zucchini Squash as Affected by Irrigation Systems and Growing Seasons. Scientia Horticulturae, 105, 177-195. http://dx.doi.org/10.1016/j.scienta.2005.01.025

[23] Yuan, B.Z., Nishiyama, S. and Kang, Y. (2003) Effects of Different Irrigation Regimes on the Growth and Yield of Drip-Irrigates Potato. Agricultural Water Management, 63, 153-167. http://dx.doi.org/10.1016/S0378-3774(03)00174-4

[24] DeCarvalho, D.F., DaSilva, D.G., DaRocha, H.S., DeAlmeida, W.S. and Sousa, E.S. (2013) Evapotranspiration and Crop Coefficient for Potato in Organic Farming. Engenharia Agrícola, Jaboticabal, 33, 201-211. http://dx.doi.org/10.1590/S0100-69162013000100020

[25] Diaz-Perez, J.C., Granberry, D., Seebold, K., Giddings, D. and Bertrand, D. (2004) Irrigation Levels Affect Plant Growth and Fruit Yield of Drip-Irrigated Bell Pepper. HortScience, 39, 748. 
[26] Wan, S., Kang, Y., Wang, D. and Liu, S. (2010) Effect of Saline Water on Cucumber (Cucumis sativus L.) Yield and Water Use under Drip Irrigation in North China. Agricultural Water Management, 98, 105-113. http://dx.doi.org/10.1016/j.agwat.2010.08.003

[27] Yavuz, D., Seymen, M., Yavuz, N. and Turkmen, O. (2015) Effects of Irrigation Interval and Quantity on the Yield and Quality of Confectionary Pumpkin Grown under Field Conditions. Agricultural Water Management, 159, $290-298$. http://dx.doi.org/10.1016/j.agwat.2015.06.025

[28] Hassanli, A.M., Ahmadirad, S. and Beecham, S. (2010) Evaluation of the Influence of Irrigation Methods and Water Quality on Sugar Beet Yield and Water Use Efficiency. Agricultural Water Management, 97, 357-362. http://dx.doi.org/10.1016/j.agwat.2009.10.010

[29] Amer, K.H., Medan, S.A. and Hatfield, J.L. (2009) Effect of Deficit Irrigation and Fertilization on Cucumber. Agronomy Journal, 101, 1556-1564. http://dx.doi.org/10.2134/agronj2009.0112

[30] Malash, N., Flowers, T.J. and Ragab, R. (2005) Effect of Irrigation Systems and Water Management Practices Using Saline and Non-Saline Water on Tomato Production. Agricultural Water Management, 78, 25-38. http://dx.doi.org/10.1016/j.agwat.2005.04.016

[31] Abubaker, B. M., Shuang-En, Y., Guang-Cheng, S., Alhadi, M. and Elsiddig, A. (2014) Effect of Irrigation Levels on the Growth, Yield and Quality of Potato. Bulgarian Journal of Agricultural Science, 20, 303-309.

[32] Adams, P. (2002) Nutritional Control in Hydroponics. In: Savvas, D. and Passam, H.C., Eds., Hydroponic Production of Vegetables and Ornamentals, Embryo Publications, Athens, 211-261.

[33] Ahmadi, H., Agharezaee, M., Haghighib, A.K. and Sepaskhah, A.R. (2014) Effects of Dynamic and Static Deficit and Partial Root Zone Drying Irrigation Strategies on Yield, Tuber Sizes Distribution, and Water Productivity of Two Field Grown Potato Cultivars. Agricultural Water Management, 134, 126-136. http://dx.doi.org/10.1016/j.agwat.2013.11.015

[34] Erdem, T., Orta, A.H., Erdem, Y. and Okursoy, H. (2005) Crop Water Stress Index for Potato under Furrow and Drip Irrigation Systems. Potato Research, 48, 49-58. http://dx.doi.org/10.1007/BF02733681

[35] Erdem, T., Erdem, Y., Orta, H. and Okursoy, H. (2006) Water-Yield Relationship of Potato under Different Irrigation Methods and Regimes. Scientia Agricola, 63, 226-231. http://dx.doi.org/10.1590/S0103-90162006000300003

[36] Ozbahce, A. and Tari, A.F. (2010) Effects of Different Emitter Space and Water Stress on Yield and Quality of Processing Tomato under Semi-Arid Climate Conditions. Agricultural Water Management, 97, 1405-1410. http://dx.doi.org/10.1016/j.agwat.2010.04.008

[37] Elkner, T.E. and Johnson, D.H. (2004) Weather Affects Seedless Watermelon Yield, But Not Fruit Size or Quality. HortScience, 39, 748. 